\title{
CONTRASTING GEOMORPHIC IMPACTS OF PRE- AND \\ POST-COLUMBIAN LAND-USE CHANGES IN ANGLO AMERICA
}

\author{
L. Allan James \\ Department of Geography \\ University of South Carolina \\ Columbia, South Carolina 29208
}

\begin{abstract}
Fluvial geomorphologists and stream restorationists often assume that preColumbian land use in parts of North America was relatively ineffective in accelerating slope erosion and floodplain sedimentation, and that erosion and sedimentation initiated by European settlement was sudden and substantial. Both of these beliefs, which underlie concepts of natural streams and legacy sediment, are in conflict with recent reassessments by cultural geographers, anthropologists, geoarcheologists, and paleoecologists with regard to substantial environmental impacts of pre-Columbian American Indians. This review paper evaluates assumptions of pristine landscapes and European disruption from a geomorphic perspective, i.e., with regard to fluvial erosion and sedimentation rates. This view is a departure from the usual emphasis on ecological or cultural landscape impacts. Geoarcheologic and sedimentologic evidence indicates that the potential for geomorphic change with land-use practices utilized by European settlers was potentially very effective in producing erosion and sedimentation in Anglo America. This can be explained by advanced technologies and economic incentives that increased the ability and motivation to rapidly clear land, plow deeply, mine, and exploit resources. A general lack of evidence of rapid sedimentation prior to the time of European contact implies that pre-Columbian agriculture was not highly disruptive geomorphically, although exceptions were likely in time and space, so this premise needs to be tested by careful study of pre-contact alluvial sequences. Examples from northern California and the southeastern Piedmont support this interpretation by documenting geomorphically stable conditions followed by episodic fluvial sedimentation after colonization. [Key words: land use change, pristine myth, preColumbian landscape, prehistoric erosion, sedimentation rates, human impacts, fluvial geomorphology.]
\end{abstract}

\section{INTRODUCTION}

Debates about environmental impacts propagated by agricultural clearing, introduction of domesticated grazing animals, the use of fire, mining, or other land-use changes often focus on changes broadly defined by ecological, biological, or landscape alterations. These changes have been described in terms of a humanized (cultural) landscape, including the effects of deforestation, plant manipulation, burning, earthworks, dark earth accumulations (terra preta), and wildlife changes (Denevan, 2006). From this perspective, a growing number of geoarcheologists, cultural geographers, and anthropologists have challenged two assumptions about human impacts on landscapes in the Americas: the pristine myth and the myth of colonial devastation. Both assumptions are commonly made by geomorphologists whose thinking may, therefore, be in conflict with prevailing concepts in anthropology, 
cultural geography, and geoarcheology. For example, concepts of "legacy sediment" that have gained momentum in geomorphic studies are predicated on the assumption of an abrupt change in geomorphic process rates after European contact. Thus, they assume relatively benign pre-Columbian sediment production and a substantial impact by European settlement.

The assumption of unaltered pre-European landscapes, referred to as the "myth of the pristine pre-Columbian landscape" (Denevan, 1992b) is often based on idyllic notions of primitive societies as the noble, primitive savage living in harmony with nature (the "Eden fallacy"). These concepts are widespread and deeply rooted in writings dating back to before the pioneer period (Krech, 1999; Mann, 2005). The assumption of benign anthropogenic impacts has been challenged with evidence of high pre-Columbian population densities, intensive agriculture, and extensive ecological changes (Butzer, 1990; 1996; Denevan 1992a; 1992b; 2003; Doolittle 1992, 2000; Whitmore and Turner, 2002; McAndrews, 1988). Descriptions and critiques of the pristine concept have been covered by several reviews, books, and volumes (Krech, 1999; Redman, 1999; Lentz, 2000; Mann, 2005; Harkin and Lewis, 2007). Patterns and degree of landscape change are difficult to fully resolve because few written contemporary descriptions exist of landscapes prior to a postulated decimation of populations by disease. Moreover, great uncertainties surround pre-contact population estimates for Anglo America (Thornton, 1987; Denevan, 1992a, 1992b). The debate over humanized landscapes has been polarized by assertions of either entirely pristine or humanized landscapes with too little regard for spatial variability or scale (Vale, 2002). Certain regions of North America may be exceptions, particularly the interior western United States and remote alpine areas (Vale, 1998, 2002). The prevailing view is that many regions of North America at the time of the arrival of Spanish explorers were humanized landscapes with a strong cultural and ecological imprint of native Americans.

Is it accurate to extend the concept of highly anthropogenic landscapes beyond cultural and ecological impacts to geomorphic impacts? Before a model of substantial and geographically extensive geomorphic change by pre-Columbian cultures in the New World is accepted, evidence of geomorphic change should be produced that goes beyond inference drawn from ecological changes. Several studies have documented pre-Columbian geomorphic change in Meso-America (Butzer, 1992; Beach et al., 2002), but relatively few studies have documented substantial off-site sedimentation impacts of pre-Columbian agriculture in temperate or continental climates of North America farther north. Doolittle (1992, 2000) provides detailed information about on-site, micro-scale, morphological features of pre-contact agricultural fields, but evidence of substantial off-site impacts from agricultural erosion remains elusive. The intensity and disruptive nature of land clearance and subsequent erosion and sedimentation varied greatly through space and time since the advent of agriculture, so interpretations of evidence should not be broadly extrapolated.

A second assumption that is commonly made is that European settlement invariably generated rapid, episodic environmental degradation. The universality of this "myth of devastated colonial landscapes" has also been challenged (Butzer, 1992, 1996). Under stable socioeconomic conditions, land-use conservation practices tended to emerge in European cultures that compensated for the increasing technologic and 
economic potential to generate erosion. In some cases, these practices were carried to the New World. For instance, an argument can be made for a dichotomy between the impacts of Spanish conquest and colonization in Meso-America and the American Southwest versus areas of North America settled by Anglo Europeans (e.g., Butzer, 1990). Thus, a distinction between cultural groups of settlers may be warranted with regard to the question of European impacts.

\section{Geomorphic versus Landscape Change}

Clearly, the presence of humanized landscapes was long underrated in North America owing to underestimates of pre-Columbian populations and agricultural activity levels (Denevan, 1992b, 2003). Yet, ecological changes do not always translate into pronounced geomorphic responses in the form of episodic erosion and sedimentation. To evaluate the geomorphic impacts of land use, a distinction is needed between changes in landscape, vegetation structure, or species composition, versus geomorphic changes such as those associated with sheet erosion, rilling, gullies, mass wasting, and sedimentation. Ecological effectiveness, based on sustainable and biological definitions of ecology (e.g., Krech, 1999; Harkin and Lewis, 2007), must be distinguished from geomorphic effectiveness of indigenous cultures based on largescale erosion and deposition. The concept of geomorphic effectiveness has been variously defined in terms of dominant land-forming events or dominant sedimenttransport events (Wolman and Miller, 1960; Wolman and Gerson, 1978). Here, the geomorphic effectiveness of human activities is used broadly to include increases in rates of sediment production, sedimentation, and related landforms such as gullies, alluvial fans, vertically accreted floodplains, canals, and anthropogenic terraces. Soil erosion episodes generated suddenly by the introduction of European agriculture, forest clearance, and mining are well documented in certain regions of North America. How common were these episodes prior to European settlement, however, and did they occur immediately and unfailingly with European settlement?

Questions of pre-Columbian geomorphic process rates and European geomorphic disturbances are not merely academic musings. Many modern environmental policies are explicitly formulated around restoration to natural conditions, and these questions have a great bearing on what is considered natural. In the United States, the goal of the Clean Water Act is to restore and maintain the chemical, physical, and biological integrity of the waters of the nation. Similarly, wilderness preservation in the United States is based on a legal definition of "wilderness" given in the 1964 Wilderness Act as " ... areas where the earth and community of life are untrammeled by man" (Public Law 88-577). Yet, if anthropogenic impacts are pervasive, where do such areas exist (Mann, 2005)?

This synthesis paper addresses geomorphic impacts of agriculture and land-use practices in Anglo America, i.e., areas of North America settled by colonists of Anglo European descent, primarily the contiguous United States and Canada. These regions may have differed in fundamental ways from other areas of North America such as in Mexico, Central America, or the Caribbean. Contemporary land-use technologies are reviewed along with associated erosion and sedimentation that occurred before and after colonization by European settlers. Pre-Columbian agricultural technologies 
in the New World are contrasted with post-European technologies and the argument is made that this contrast indicates a substantially greater geomorphic potential of post-colonial land use in many areas of Anglo America. Direct evidence is limited for pre-Columbian anthropogeomorphic impacts on fluvial and aquatic systems in many areas of North America settled by Anglo Europeans. This is contrasted with abundant evidence of European-induced geomorphic change. The paper closes with field evidence from two locations in the USA - a large river in northern California and a small watershed in the southeastern Piedmont-that show evidence of low sedimentation rates followed suddenly by catastrophic sedimentation after arrival of European settlers.

\section{CONTRASTING TECHNOLOGIES}

Contrasts between pre-Columbian and European land-use practices in North America are a central premise of this paper. This section outlines (1) development of agricultural and other technologies in Eurasia that greatly increased the geomorphic potential of land use, (2) limits to anthropogeomorphic change in pre-Columbian North America, and (3) impacts resulting from the introduction of European technologies to temperate North America. In the Old World, the dominant agents of early Neolithic soil erosion were land clearance, grazing, and fires (e.g., Butzer, 1982; Van Andel et al., 1990). Land clearance and fire were also important in early New World agriculture, but large grazing animals were not domesticated prior to European contact. Anthropogeomorphic processes accelerated with agriculture as groups became adept at clearing land and attained higher population densities. Hydrogeomorphic responses to land-use change varied with the intensity and timing of land-use changes, climate, position within watersheds, geologic character, and history of watershed and channel systems (Brierley et al., 2005). Intensive deforestation and agriculture tended to increase runoff, susceptibility of landscapes to soil erosion, and sedimentation (Knox, 2001). Based on a quantitative global survey of soil erosion data, Montgomery (2007) estimated that upland erosion and sediment production rates increased an average of one to two orders of magnitude under conventional plowing. In extreme cases, river systems responded with aggradationdegradation episodes and channel and floodplain metamorphosis (James, 2010).

\section{Intensification of Land Use in Eurasia}

Evidence from alluvial archeology reveals substantial anthropogenic landscape change during the Holocene in much of Eurasia (Europe, Asia, and North Africa). Agricultural technology advanced far beyond other regions owing to the lack of geographic barriers (Diamond, 1997). High geographic connectivity allowed the rapid spread of ideas and materials through dispersion, migration, and conquest. Agriculture and trade spread rapidly in prehistory westward from Asia (Hobson, 2004) and from the Mediterranean to northwestern Europe (Cunliffe, 2008). A high rate and number of migrations and conquests from Asia, the Middle East, and across Europe occurred in prehistory and rapidly spread technologies. For example, the Danube River provided a corridor from the Aegean Sea into central Europe through which 
early Neolithic agriculture spread about $1500 \mathrm{~km}$ in 500 years between 7500 and 7000 BP (Cunliffe, 2008). Areas such as the Americas, Australia, and sub-Saharan Africa were isolated by oceans, deserts, mountains, tropical rainforests, or other geographic barriers that inhibited the spread of technology and domesticated plants and animals. The tropics harbored diseases that were devastating to Europeans, and other pathogens plagued their cattle (Diamond, 1997).

Strong geographic interconnectivity in Eurasia and early developments in transportation technology resulted in voluminous commerce across large areas. Advent of the wheel and seaworthy ships led to inter-regional transport of massive quantities of agricultural products, timber, ore, and other resources. Horses had been domesticated by $5500 \mathrm{BP}$ and began to replace or augment oxen for transporting freight (Cunliffe, 2008). Draught animals facilitated transport of goods to markets and harbors where surpluses could be traded and exported. Distant markets increased incentives to clear land and raised the potential for episodic upland erosion and lowland sedimentation. Further technological developments, such as the harness, steel plow shares, heavy wheeled plows, machinery, and explosives, enhanced the potential geomorphic effectiveness of agriculture and mining in Eurasia. For instance, sedimentation in the eastern Mediterranean during the Roman Period was particularly erosive (e.g., Beach and Luzzadder-Beach, 2008).

Land clearance was greatly facilitated and encouraged during the Mechanical Revolution with the development of water power. Water wheels proliferated across Europe during the Middle Ages, initially for grist mills, but also for a growing list of uses including saw mills that expedited timbering. European technology became highly effective at forest clearance, deep plowing, and mining, and this led to increasing production of grain, timber, and ore. By the Middle Ages, many European basins had already experienced multiple episodes of forest clearance, erosion, and sedimentation (Lang et al., 2003; de Moor et al., 2008). The rise of mercantilism in Europe during the colonial period further increased the potential for geomorphic effectiveness by motivating aggressive extraction and export of natural resources.

\section{Agricultural Technology and Geomorphic Impacts in Pre-Columbian North America}

Anthropogenic influences in North America had begun by 11,000 BP (Taylor et al., 1996; Waters and Stafford, 2007). As in Eurasia, however, early humans in North America had low population densities and minimal effects on geomorphic change, other than their impacts on grazing animals and the use of fire. During the midHolocene, human activities were influenced by climate changes associated with the Altithermal, which were highly variable in space and time across North America (Dean et al., 1996; Meltzer, 1999). With the domestication of corn and squash and the spread of agriculture, population densities and land-use intensities grew, social hierarchies emerged, and, in some places, urban centers developed. For much of the 20th century, it had been presumed that pre-Columbian landscapes in the Americas were pristine and undisturbed by human activities. Modern studies, however, document extensive ecological and cultural changes to the Pre-Columbian landscape by sophisticated field cropping and irrigation methods (Doolittle, 2000; Whitmore and Turner, 2002; Denevan, 2003). These practices led to an anthropogenic landscape 
prior to the colonial period (Butzer, 1990; Redman, 1999; Delcourt and Delcourt, 2004). Agricultural societies usually have substantial ecological imprints on the environment, but questions remain about the degree and manner in which these impacts extended to geomorphic responses and how this varied in time and space (Brierley et al., 2005).

Although agriculture began early in multiple hearths of the Americas, and advanced societies emerged with sophisticated concepts of astronomy and mathematics, the range of land-working tools available to indigenous groups prior to European contact was narrow. For example, the wheel was not utilized for transportation or machinery anywhere in the pre-Columbian Americas, and large draught animals had not been domesticated in North America (Diamond, 1997; Goudie, 2005). Thus, transport of timber, agricultural goods, and mining products throughout North America was limited to river routes and human portage. Land clearance was accomplished by girding trees with hand tools made of wood, stone, and shell, in conjunction with burning. Although population densities were higher and land clearance for agriculture was more intense than previously assumed (Denevan, 1992a; Doolittle, 1992, 2000), the geomorphic effectiveness of agriculture was limited by technologies that required large amounts of labor and often left tree stumps and root mats intact. Compared to the technologies introduced by Europeans, indigenous land-use practices were labor intensive and far less destructive to soil and slope stability.

Spatial analyses of North American land use in prehistory are consistent in depicting non-uniform patterns of agriculture and land-use intensity (Fig. 1). Not all these cultures or land uses were present at the time of European contact. Butzer (1990) differentiated between supplementary, extensive, and intensive agriculture. Supplementary agriculture (not shown on Fig. 1) was practiced by foraging groups and is unlikely to have been sufficiently disruptive to generate much erosion or sediment. Butzer identified intensive land use in two regions: the eastern Pueblo culture in the Southwest and along the mid-Atlantic to southern New England coast. He also mapped other areas (not shown) as the maximum expansion of agriculture by A.D. 1100 prior to decline. Denevan's (1992b) map of the Western Hemisphere shows an "approximate limit to agriculture" in Anglo America that is largely in agreement with Butzer's map and restricts substantial agricultural activity to the eastern and southwestern United States and northwestern Mexico. By these analyses, large expanses of Anglo North America were beyond the limits of substantial agriculture. An appreciation for the spatial variability of pre-settlement land use is prerequisite to a sophisticated understanding of pre-contact conditions. The following discussion outlines examples of cultural developments in eastern North America and California.

Eastern North America. Historical documentation of pre-Columbian agriculture in the eastern United States is poor, other than a few observations by early explorers and settlers. Most of what is known comes from geoarcheologic or palynologic evidence, which tends to be much better represented in some regions than in others. The Archaic cultural period ( 9,000-3000 BP) was associated with the spread of humans and occupation of most forested areas by a small, sparse population of foragers (Schuldenrein, 1996). The introduction of squash (Cucurbita pepo) and bottle gourd (Lagnearia siceraria) across eastern North America from Mexico suggests early horticultural experimentation between 7000 and 4000 BP (Delcourt and Delcourt, 


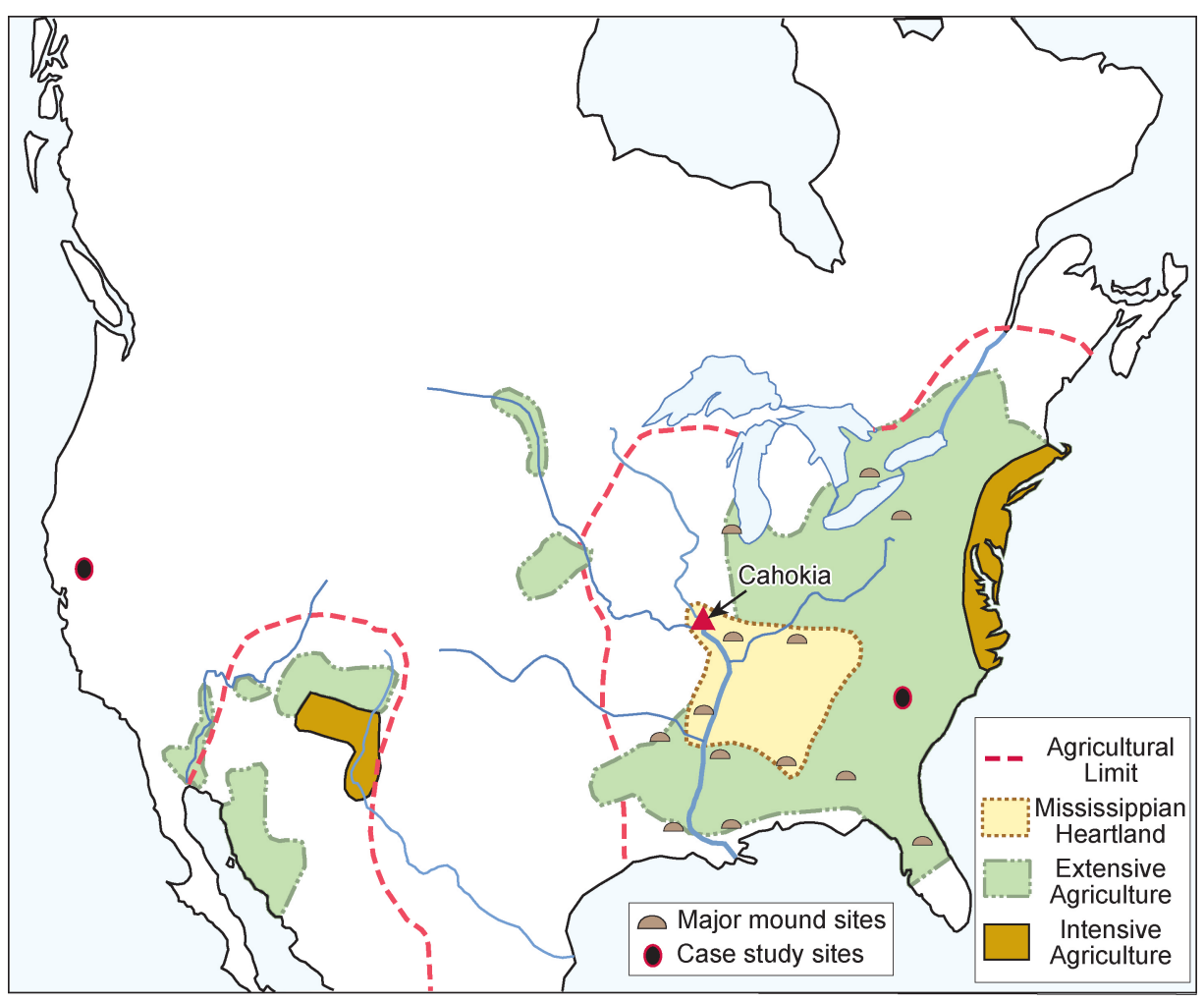

Fig. 1. Pre-contact agriculture and cultural features. Sources: Agricultural limit and mounds from Denevan (1992) based on Donkin (1979); extensive and intensive agriculture from Butzer (1990); Mississippian Heartland from Delcourt and Delcourt (2004).

1987). Tools and other cultural artifacts of this period included stone axes, spear throwers (atlatls), and early ceramics (Sassaman, 1996). The Woodland cultural period ( 2000-1000 BP) was associated with the advent of pottery, increased population densities, intensification of horticulture, and clearing of bottomland forests and field areas along floodplains and low terraces of large rivers. The Woodland culture had a limited geomorphic effectiveness, although some evidence of an impact has been detected in lake sediments. For example, analysis of two sediment cores from Cayuga Lake, a finger lake in New York state, indicated increased variability in carbonate and carbon isotopes beginning ca. $2.4 \mathrm{ka}$ BP, which was interpreted as evidence for human clearance in the watershed (Mullins et al., 2011). By $1.6 \mathrm{ka}$ BP (400 AD), toward the end of the Middle Woodland period, agricultural production was contributing substantially to the intensive gathering economy, and large burial and effigy mounds were being constructed in spite of population densities as low as one person per $2.6 \mathrm{~km}^{2}$ (Butzer, 1990).

The Mississippian cultural period (1000-500 B.P.) was associated with the emergence of hierarchical societies, extensive trade routes, construction of cities and towns, planting of maize (Zea mays) and beans (Phaseolus vulgaris), and intensification of 
riparian forest clearance (Delcourt and Delcourt, 1987, 2004; Butzer, 1990). The "Heartland" of Mississipian culture was mapped by Delcourt and Delcourt (2004) in the lower Mississippi, Ohio, and Tennessee River valleys, although the culture extended well beyond this core region as is evidenced by the distribution of mounds (Fig. 1). Agriculture during this period was concentrated on or near floodplains (Muller, 1978; Brown, 1997). Farming was based on hoes and digging sticks and analogous to simple Neolithic farming in Europe (Butzer, 1990; Doolittle, 2000). By Late Mississipian time, vegetation alteration along large river valleys was extensive. In the Southeast, near the end of Mississippian time, Hernando de Soto's party of Spanish explorers described extensive fields of maize, beans, and squash (Doolittle, 1992, 2000). Farther north, evidence of vegetation changes attributable to humans during this period has been shown by pollen and charcoal records (Clark and Royall, 1995). Upland land clearance in small watersheds between 750 and 550 BP has been inferred from catchment-integrated biomass carbon sampled in cave sediment and speleothems (Springer et al., 2010). In southern Ontario, the introduction of late Holocene agriculture corresponds with Neoglacial cooling, so it is difficult to separate the effects of land use from climate change. Munoz and Gajewski (2010) concluded from pollen assemblages that the transition from deciduous to boreal forest was climatically driven (see Hupy and Yansa, 2009 for discussion of coolingrelated late Holocene vegetation changes in Michigan), while secondary succession of beech-maple forest to grasses, poplar, and waste-heap species was governed by human activities. Overall, land-use changes were concentrated in lowlands. In New England, for instance, historical and paleoecological evidence indicate that pre-contact disturbance to uplands was minimal (Foster et al., 1998).

The most intensive land use began in relatively flat lowland sites, although wood collection near some population centers moved upslope after a period of time, and some degree of upland erosion is likely in limited areas of intensive land use. Cahokia, a major center of Mississippian culture (Fig. 1), provides an extreme example of a cultural landscape in the east. Populations at Cahokia peaked around 700 BP at $\sim 25,000$ persons in a $300 \mathrm{~km}^{2}$ area (83.3 persons per $\mathrm{km}^{2}$ ) (Delcourt and Delcourt, 2004). Populations declined until 525 BP and the center was abandoned by 500 BP, before European contact. Preferred settlement sites of the Mississippian culture were slightly elevated areas on the floodplains of large rivers, such as old channel banks along oxbow lakes. Substantial ecological changes occurred in and around Cahokia, with deforestation extending into the uplands 10 to $15 \mathrm{~km}$ from the city. Analyses of timber posts and charcoal indicate deforestation of floodplain sites by $1600 \mathrm{BP}$ and nearby upland sites by 950 BP. This led Delcourt and Delcourt (2004) to infer that accelerated erosion and siltation may have destabilized river regimes regionally. Such inferences are intriguing, but a stratigraphic record of erosion and sedimentation is needed to ascertain the extent and timing of such events. Geomorphic effects on alluvial sequences of extensive land-use practices during the Mississippian cultural period remain to be demonstrated. Owing to the decimation of indigenous populations by diseases introduced by Europeans, the most environmentally pristine period in the Americas was approximately two centuries after the time of initial contact with colonists (Denevan, 1992b). Thus, a period of cultural quiescence and potential for geomorphic stability may have preceded European disruption, and this should be 
considered in interpreting the alluvial stratigraphic record. A possible scenario is that some degree of anthropogenic sedimentation did occur along some floodplains, but stabilization followed for a sufficient period of time to allow substantial pedogenesis on the surface of the deposits prior to European arrival. These increased deposition rates may be difficult to distinguish from those caused by climate change.

Central Valley of northern California. In the Central Valley of California prior to European contact, indigenous people were hunters and gatherers with tools primarily of stone, bone, and shell (Krober, 1922; Doolittle, 2000). At contact, seven distinct languages were spoken by Indians in the Central Valley, but the groups interacted regularly (Rosenthal et al., 2007). The period known locally as the Upper Archaic (2500-850 BP) saw the development of specialized bone tools and included permanent settlements in some locations such as large mounded villages in the Sacramento Delta and major rivers. The Emergent Period (500-1800 AD) in the Central Valley saw the appearance of new technologies such as the bow and arrow, the appearance of populated settlements along rivers, and the use of fish weirs (Rosenthal et al., 2007). An increase in population occurred during the upper Archaic and Emergent periods and by the time of European contact, large villages were observed along some of the rivers. John Bidwell reported approximately 1000 people in an Indian village near Colusa along the Sacramento River in 1848 (Powers, 1877). Settlements on the river were often semi-permanent and occupied seasonally. The limited technology for land clearance and the limited use of agriculture in the region constrain the potential for substantial geomorphic disruptions primarily to the use of fire.

\section{Limited Evidence of Rapid Pre-Columbia Sedimentation Rates}

High anthropogeomorphic effectiveness in pre-Columbian temperate North American regions should not be assumed without direct evidence of erosion and sedimentation. However, stratigraphic and sedimentological evidence of elevated sedimentation rates prior to Anglo-American settlement is limited. Globally, the mean annual rate of agricultural land denudation is $\sim 643 \mathrm{~m} \mathrm{Ma}^{-1}$, compared to the long-term erosion rate of $\sim 24 \mathrm{~m} \mathrm{Ma}^{-1}$ (Wilkinson, 2005), so the current rate in modern agricultural areas is $\sim 28$ times long-term erosion rates. Lacustrine and fluvial sediment storage provides one of the best-preserved records of long-term sedimentation rates. Although lake and floodplain deposits integrate the production of sediment from upstream contributing areas, the signal from an individual watershed attenuates and is diluted greatly downstream. Interpretations of these deposits should take into account the high proportion of sediment stored close to the source (Beach, 1994). Some lake sedimentation studies have documented increased sedimentation from aboriginal land use, but these are generally subtle compared to postcontact changes and are usually included in conditions described as "baseline" or "natural" sedimentation rates.

In several areas of Anglo North America, stable floodplain soils are buried by postsettlement alluvium separated by an abrupt contact (Fig. 2). This stratigraphy, where it occurs, indicates a lack of pre-Columbian episodic sedimentation at that site and, if ubiquitous along a river, suggests a relatively stable period of upland land use during the period preceding generation of the overlying historical alluvia. The lack of 

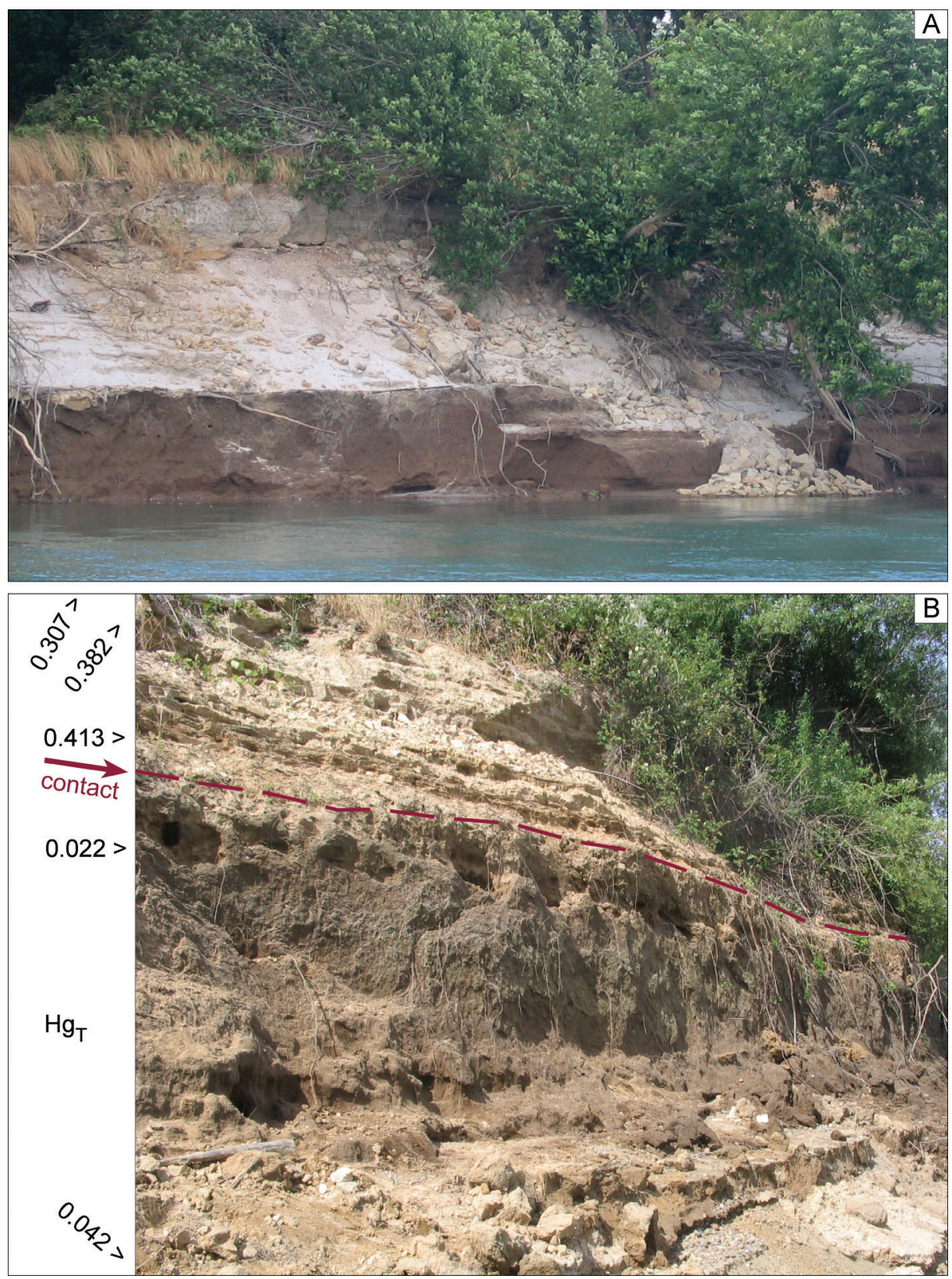

Fig. 2. River-bank exposures on lower Yuba River, California, showing historical alluvium over stable floodplain soils. A. Abrupt contact between dark soil overlain by white hydraulic mining sediment. B. Contact (dashed line) between stable floodplain soil and overlying stratified historical alluvium. Concentrations ( $\mathrm{ppm}$ ) of total elemental mercury in sediment samples (at left) provide a reliable indicator of mining sediment in this basin (cf. James et al., 2009). 
evidence for substantial early sedimentation suggests low geomorphic effectiveness and corroborates inferences about the relative ineffectiveness of pre-Columbian land use that can be drawn from the limited technology of pre-contact societies.

\section{INTRODUCTION OF EUROPEAN AGRICULTURE TO NORTH AMERICA}

Although pre-Columbian landscapes were far from ecologically pristine, the introduction of European agriculture to steep slopes that had never been clear-cut or plowed had the potential to generate an unprecedented episode of anthropogenic erosion and sedimentation. The goals of colonists were often different than goals of European agriculturalists. The conquest of areas for the primary purpose of resource exploitation was often accompanied by extensive land clearance, plowing, or mining without regard to land management practices. Colonial expansion, when coupled with aggressive agriculture, timbering, or mining for overseas export, had the potential to greatly accelerate erosion (Brierley et al., 2005). Colonists had the technology to rapidly clear land, had economic incentives to do so, and often lacked disincentives normally imposed by social mores or limited quantities of land. This often resulted in land-use practices with a high geomorphic potential. In some regions, land-use intensities were driven to new extremes, well beyond pre-Columbian levels of production. Land was cheap in the New World, so principles of land stewardship and soil conservation were often neglected in favor of a rapidly advancing frontier. In many cases, the response to European colonization and agriculture was an episode of rapid sediment production and sedimentation on previously stable floodplains, as documented by the studies in Table 1. These studies include evidence of order-of-magnitude increases along the mid-Atlantic coast where Butzer (1990) mapped intensive pre-contact agricultural activity (Fig. 1). Floodplain sedimentation rates in the upper Midwest increased by an order of magnitude in response to the shift to European agricultural land use in the early 19th century (Knox, 2006), and resulted in deep historical deposits resting abruptly over well-developed floodplain soils (Knox, 1972, 1977, 1987, 2002). Pre-settlement rates of Holocene floodplain vertical accretion ranged from an average of only $0.2 \mathrm{~mm} \mathrm{yr}^{-1}$ in main tributaries to $0.9 \mathrm{~mm} \mathrm{yr}^{-1}$ along the upper Mississippi River. In contrast, historical vertical accretion rates over the past 200 years average between 2 and $20 \mathrm{~mm} \mathrm{yr}^{-1}$ (Knox, 2006). Floodplain aggradation in tributaries was accompanied by increased overbank flood frequencies and higher flow velocities that generated bank erosion and passed sediment farther down valley. In wetlands along the Chesapeake Bay, an 1800-year stratigraphic record indicates that mean sedimentation rates increased by an order of magnitude from $0.5 \mathrm{~mm} \mathrm{yr}^{-1}$ prior to 1700 to $6.0 \mathrm{~mm} \mathrm{yr}^{-1}$ after Anglo-American settlement (1730-1750) (Hilgartner and Brush, 2006). Severe gullying and sedimentation associated with Providence Canyon, Georgia provides an extreme example of the erosion common in the southeastern USA after colonization (Magilligan and Stamp, 1997; Hyatt and Gilbert, 2000).

Many studies have documented lower rates of lacustrine sedimentation prior to European colonization. Analysis of 12 sediment cores from Green Lake, New York state, revealed an abrupt sevenfold increase in sedimentation rates $(0.1$ to $0.7 \mathrm{~mm}$ $\mathrm{yr}^{-1}$ ) beginning with European land clearance in the early 1800 s and accompanied by 
Table 1. Representative Studies in Anglo North America Indicating Abrupt Increases in Alluvial Sedimentation Rates before and after European Settlement

\begin{tabular}{|c|c|c|}
\hline Location & Synopsis & Source \\
\hline $\begin{array}{l}\text { Upper Mississippi } \\
\text { and its upper Midwest } \\
\text { tributaries }\end{array}$ & $\begin{array}{l}\text { Prehistoric alluvial soil buried by } \\
\text { stratified alluvium with abrupt } \\
\text { contact }\end{array}$ & $\begin{array}{l}\text { Happ, 1944; Knox, 1972, 1977, 1987, } \\
\text { 2002, 2006; Magilligan, 1985, 1992; } \\
\text { Miller et al., 1993; Lecce, 1997; } \\
\text { Faulkner, 1998; Lecce and Pavlowsky, } \\
\text { 2001, } 2004\end{array}$ \\
\hline $\begin{array}{l}\text { Brazos River, central } \\
\text { Texas }\end{array}$ & $\begin{array}{l}\text { Dated prehistoric alluvial soil } \\
\text { buried by modern alluvium }\end{array}$ & Waters and Nordt, 1995 \\
\hline $\begin{array}{l}\text { Mid-Atlantic and } \\
\text { Southern Piedmont }\end{array}$ & $\begin{array}{l}\text { Well-developed alluvial soil buried } \\
\text { by stratified historic alluvium }\end{array}$ & $\begin{array}{l}\text { Happ, 1945; Trimble, 1974, 1977; } \\
\text { Costa, 1975; Jacobson and Coleman, } \\
\text { 1986; Ruhlman and Nutter, 1999; } \\
\text { Bain and Brush, 2005; James, 2006; } \\
\text { Walter and Merritts, 2009; Merritts et } \\
\text { al., } 2011\end{array}$ \\
\hline $\begin{array}{l}\text { Mid-Atlantic and } \\
\text { Southeastern Coastal } \\
\text { Plain }\end{array}$ & $\begin{array}{l}\text { Stable floodplain surfaces buried } \\
\text { by mineral soil from nearby } \\
\text { uplands; accelerated delta } \\
\text { sedimentation }\end{array}$ & $\begin{array}{l}\text { Phillips, 1992, 1993, 1997; Pasternack } \\
\text { et al., 2001; Hilgartner and Brush, } \\
2006\end{array}$ \\
\hline $\begin{array}{l}\text { Central Valley, } \\
\text { California }\end{array}$ & $\begin{array}{l}\text { Well-developed alluvial soil buried } \\
\text { by anthropogenic sediment }\end{array}$ & $\begin{array}{l}\text { James, 1989, 1991, 2006; Florsheim } \\
\text { andMount, } 2003\end{array}$ \\
\hline
\end{tabular}

increases in nutrients, metals, terrigenous organics, and detrital quartz and dolomite that give the historical upper layers a distinctive grey color (Hilfinger et al., 2001). A well-dated sediment chronology from 1026 to 2002 A.D. in the Pettaquamscutt River estuary displays statistically significant increases in varve thicknesses between 1695 and 1700 A.D. at the initiation of colonization and again between 1950 and 1960 when residential development began in the watershed (Hubeny et al., 2009).

Geomorphic responses to European colonization varied greatly with cultural groups, climate, and physiographic region. To evaluate the relative importance of pre-Columbian geomorphic impacts, distinctions should be made between the cultures of the settlers and the environments of the settlements. Some land management systems employed conservation strategies derived from European cultures. For example, Spanish livestock grazing in central Mexico applied management practices that inhibited soil erosion and alluviation until the 18th century when populations grew. Butzer (1996) dismissed the degradational impacts of early Spanish livestock grazing in a valley of central Mexico and described importation of a well-managed Mediterranean agricultural system that had been sustained for 200 generations. Accelerated soil erosion and alluviation did not appear in the region until the 18th century when population pressures rose.

These factors suggest a hypothetical distinction between the geomorphic effectiveness of Spanish settlements in subtropical Meso-America and Anglo-American settlements in temperate North America. Many Spanish settlers recognized landscapes of indigenous Indians, learned their land-use practices, and sought to assimilate the people (Butzer, 1990). Despite widespread cases of brutality, suppression, and 
confiscation of land, deep-seated cultural and sociopolitical policies mitigated the inhumane treatment of people conquered by the early Spanish. These policies were based on two traditions: (1) recognition and accommodation of local customs, a tradition derived from Roman practices; and (2) concepts of charity toward the needy, a tradition derived from religious beliefs and practices (Carter, 2009). In contrast, many Anglo-American settlers came from urban rather than farming traditions, lacked a culture of land stewardship, did not assimilate local natives or adopt indigenous land-use practices, and came from northern climates with glaciated landscapes. Even when a stable sociopolitical system was introduced with sound land management principles, severe damage could result where agricultural practices were based on experience from a different environment (Butzer, 1996). Anglo Europeans lacked experience with the intense subtropical storms and deeply weathered residual soils that they encountered in the south and central United States, so European land management practices were not well adapted to the environmental conditions there. In the southern Piedmont of North America, Anglo American settlers applied farming techniques derived largely in glaciated northwestern Europe to a subhumid landscape with thick, deeply weathered residual soils. The lack of appropriate experience with the new environment, combined with a colonial export economy and vast tracts of open land to the west, led to poor land management practices, severe erosion, and thick floodplain deposits overlying prehistoric soils (Happ, 1945).

\section{Two Case Studies: Abrupt Post-Contact Increases in Sedimentation Rates}

Terrace stratigraphy exposed in cutbanks along the Feather River in the Sacramento Valley reveals well-developed soils overlain abruptly by thick, highly stratified historical alluvium (Fig. 3). The buried soil at mid-bank corresponds with a tree line and a topographic berm that formed because the argillic B horizon is relatively resistant to erosion. The thin A horizon lacks primary depositional features, indicating low rates of overbank sedimentation in the prehistoric period. The interpretation that the abrupt contact represents the pre-settlement soil surface is corroborated by pedogenic evidence, mineralogy, and geochemistry. Silty sediment below the contact has strong pedogenic development, while overlying sediment is sandy, quartzose, stratified, and lacks pedogenesis. Moreover, high concentrations of total mercury $\left(\mathrm{Hg}_{\mathrm{T}}\right)$ provide an unequivocal marker for the historical alluvium due to introduction of non-native mercury by mining operations in the mountains (Fig. 4). Whereas the pre-settlement soil apparently received sediment very slowly and was assimilated by pedogenesis in a cumulic A horizon, the $3 \mathrm{~m}$ of overlying sediment was deposited in less than 100 years after 1861 .

A small watershed in the Sumter National Forest of South Carolina has excellent exposures of the stratigraphy due to channel incision below a bridge (Fig. 5). The pre-settlement stream bank at this location was less than a meter above the bed and the soil is heavily gleyed, indicating reducing conditions. A $2.7 \mathrm{~m}$ thick layer of historical alluvium overlies the pre-settlement alluvium at this site over an abrupt, wavy contact with $1.6 \mathrm{~m}$ of tan sand followed by another $1.1 \mathrm{~m}$ of mixed sand, transitioning to orange sand. Following the pre-settlement soil downstream from this 

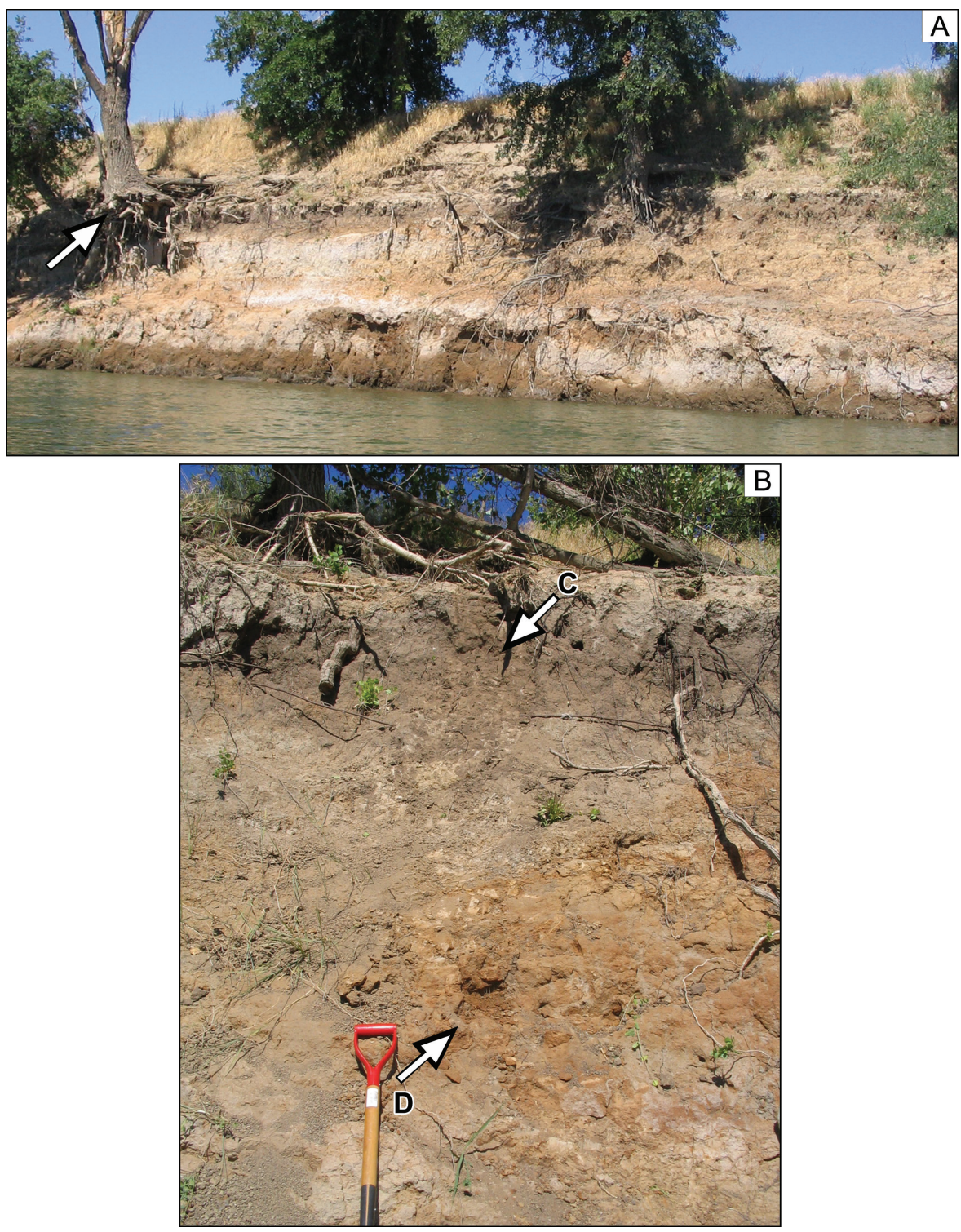

Fig. 3. Right-bank exposures on the lower Feather River, California, showing thick historical alluvium over a stable soil. A. Tree is growing in well-developed pre-contact soil (arrow) buried by $>2 \mathrm{~m}$ of mining sediment. B. Distinct A horizon indicates slow rates of sedimentation in prehistoric period (C and D shown in this figure are sample sites in Figure 4).

location reveals an abundance of waterlogged organics and gleyed mineral material associated with pre-contact wetland conditions. A tree stump was located in rooting position at the base of the section near the channel at the downstream end of a point bar and cut bank. The outer wood of the stump was ${ }^{14} \mathrm{C}$ dated as historical in 


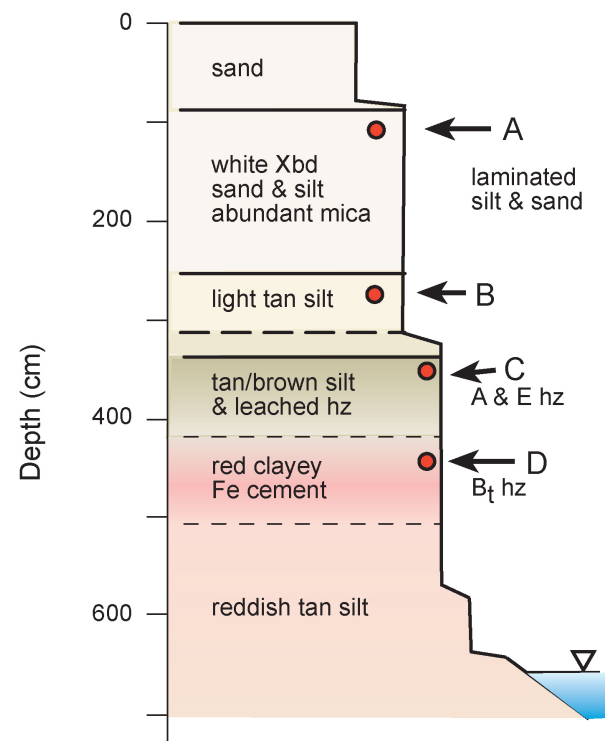

Fig. 4. Stratigraphic section of exposure near site in Figure 3. Hg concentrations confirm thick surface layer is historical in age and that prehistoric contact is abrupt. Total mercury concentrations in A and B were 0.10 and 0.14 ppm, respectively, versus 0.04 ppm in C and D. Adapted from James et al. (2009).

age with three possible ranges: 1665-1695, 1725-1815, or 1920-1950 cal AD (1 $\sigma)$. Based on the history of the area, the 1920 to 1950 date is considered most likely for deep burial of the tree, which apparently killed it. This indicates that episodic sedimentation of this tributary began late in the history of settlement of the South Carolina Piedmont in response to intensification of agriculture rather than during the initial settlement of the region. Following deep aggradation and reforestation at this site, the channel entrenched to form high, vertically scarped terraces that provide excellent exposures of historical alluvium.

Bedrock is exposed in the channel bed at several locations in this area, constraining the vertical changes in the stream. Photographs of the bank stratigraphy $\sim 80 \mathrm{~m}$ downstream of the section in Figure 6 show about $2.5 \mathrm{~m}$ of historical alluvium over an abrupt contact with the pre-settlement soil. The close-up shows gleyed silts with no primary depositional structures below the wavy contact, which may represent de-watering of saturated sediment after historical deposition of the overlying highly stratified sands. The stream bed is consistently $\sim 1.5 \mathrm{~m}$ below the contact and has frequent exposures of bedrock, so pre-contact stream banks were no higher than that. Although this reach aggraded deeply and rapidly, the channel remains in its predisturbance location and the low banks were continuous across the valley bottom as was shown by coring the floodplain (James, 2006). The channel is now entrenched more than $3 \mathrm{~m}$ below the historical terrace surface, back down to a thin veneer of gravel over bedrock.

The alluvial stratigraphy at this site indicates stable geomorphic conditions that were common in small tributaries prior to European settlement in the Southeastern 


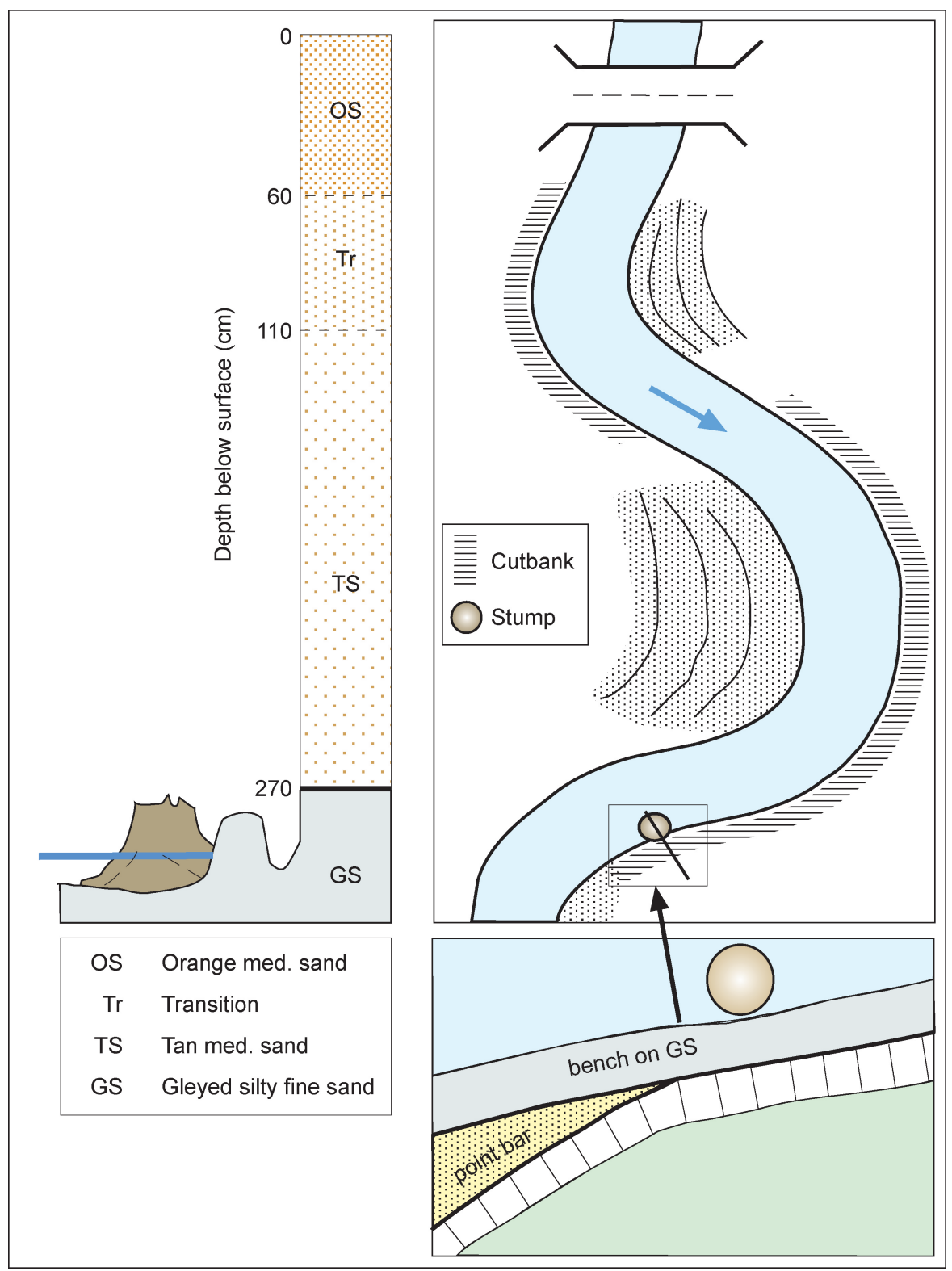

Fig. 5. Stratigraphic section and map of historical terrace on Storm Creek, South Carolina Piedmont. Section at left shows $2.7 \mathrm{~m}$ of historical sediment overlying prehistoric gleyed silty sand. Sedimentation began with a thick layer of tan sand, followed by a half meter of sand of intermediate color (transition), and $>0.5 \mathrm{~m}$ of orange sand. Map at right shows position downstream from cutbank of section and tree stump dated to historical period. Prehistoric stream banks were low but channels aggraded deeply and then entrenched to form high, steep-walled terraces. 

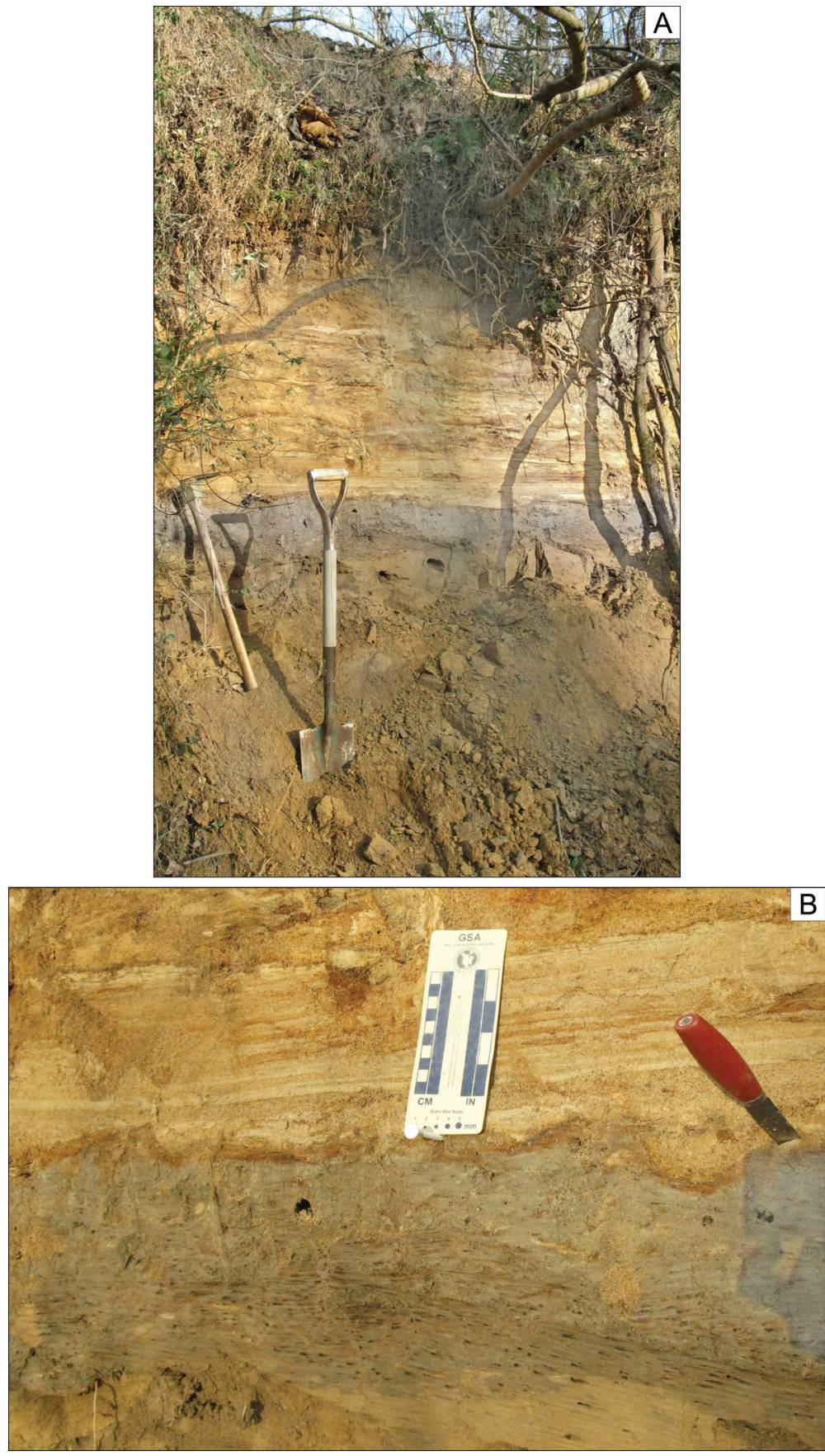

Fig. 6. Historical terrace scarp exposed $\sim 80 \mathrm{~m}$ downstream from section shown in Figure 5 . A. Top of pickax is in abrupt wavy contact. B. Detail of contact between pre-contact gleyed silty sand and overlying plane-bedded tan and orange historical sands with strong primary sedimentary structures. 
Piedmont (Happ, 1945). Small channels on or close to bedrock with low thin banks indicate limited volumes of pre-contact alluvial storage in the watershed. When considered in conjunction with evidence of wetlands, the lack of alluvial storage in this environment indicates that pre-contact sediment delivery rates from the uplands were modest and that the sediment delivered was largely transported out of the basin. Although no direct evidence has been found, the wetland soils may reflect the activity of beavers (Castor canadensis). Sometime after the arrival of European settlers, an episode of sheet and gully erosion occurred that filled valley bottoms with sediment. A similar sequence of orange sand over tan sand was observed by Happ (1945) in Ferguson Creek of Spartanburg County, South Carolina. He interpreted the sequence as deposits of tan sand from shallow sheet and rill erosion during the early phases of erosion, followed by deposits of orange sand generated by deep gully erosion into metamorphic rocks.

\section{CONCLUSION}

Discerning the geomorphic history of a place is an important step in the proper management of the local environmental system, and overly generalized concepts of land-use impacts should be avoided. Assumptions that European land-use practices were introduced to pristine landscapes in the Americas should be critically evaluated for individual watersheds in each region. The cultural and ecological impacts of pre-Columbian societies on landscapes were generally much greater than was assumed in the early 20th century and were extensive across much of southwestern and eastern North America. The effectiveness of pre-Columbian agriculture in creating geomorphic responses in Anglo America was constrained, however, by limited technologies for clearing land and moving commodities to markets. The lack of animal power for plowing or hauling freight, and the lack of the wheel for transportation or machinery, constrained the intensity of pre-Columbian land use relative to European practices. Thus, challenges to the myth of pristine pre-Columbian landscapes do not justify assumptions of intensive pre-European geomorphic effectiveness in these regions. Some episodes of pre-Columbian anthropogeomorphic impacts likely occurred in Anglo America, especially in areas of the southwestern and eastern USA. Presumably these episodes occurred intermittently in association with major population centers such as Cahokia, although the spatial extent and duration of these geomorphic events needs to be documented.

By comparison, land use associated with European agriculture, deforestation, and mining had the potential to be much more geomorphically effective, and numerous cases have been documented of aggradation-degradation episodes instigated by European colonization. Agricultural technology and land-use practices introduced by colonists spread rapidly westward with the frontier. In many cases, frontier settlers cleared land, worked it for a generation or two, and then moved farther west to clear new lands. Little attention was paid to soil conservation by frontier farmers, and the result was often severe erosion. Abundant evidence of episodic floodplain aggradation is well documented in the scientific literature, although a comprehensive spatial analysis is needed. In spite of the high potential for episodic erosion and sedimentation following the introduction of European agricultural practices, this response 
should not be assumed to have been ubiquitous. Some European colonies employed land-management practices that had been used in Europe for many generations and did not cause accelerated soil erosion and sedimentation. Other intensive land-use practices occurred on landscapes with low sensitivities to geomorphic change and may not have generated substantial responses. As is commonly the case, places have unique histories and characteristics and geomorphologists must consult the local evidence to interpret the local history of geomorphic change.

Acknowledgments: I thank Jonathan Phillips and an anonymous reviewer for keen insights, corrections, and constructive critiques of an early manuscript. This paper was greatly enhanced by that process.

\section{REFERENCES}

Bain, D. J. and Brush, G. S. (2005) Early chromite mining and agricultural clearance: Opportunities for the investigation of agricultural sediment dynamics in the eastern Piedmont (USA). American Journal of Science, Vol. 305, 957-981.

Beach, T. (1994) The fate of eroded soil: Sediment sinks and sediment budgets of agrarian landscapes in southern Minnesota, 1851-1988. Annals, Association of American Geographers, Vol. 84, 5-28.

Beach, T. and Luzzadder-Beach, S. (2008) Aggradation around Kinet Höyük, an archaeological mound in the Eastern Mediterranean, Turkey. Geomorphology, Vol. 101, 416-428.

Beach, T., Luzzadder-Beach, S., Dunning, N., Hageman, J., and Lohse, J. (2002) Upland agriculture in the Maya Lowlands: Ancient Maya soil conservation in northwestern Belize. Geographical Review, Vol. 93, 372-397.

Brierley, G. J., Brooks, A. P., Fryirs, K. A., and Taylor, M. A. (2005) Did humidtemperate rivers in the Old and New Worlds respond differently to clearance of riparian vegetation and removal of woody debris? Progress in Physical Geography, Vol. 29, 27-49.

Brown, A. G. (1997) Alluvial Geoarchaeology. Floodplain Archaeology and Environmental Change. Cambridge, UK: Cambridge University Press.

Butzer, K. W. (1982) Archaeology as Human Ecology. Cambridge, UK: Cambridge Univ. Press.

Butzer, K.W. (1990) The Indian legacy in the American landscape. In M. P. Conzen, ed., The Making of the American Landscape. Boston, MA: Unwin Hyman, 27-50.

Butzer, K. W. (1992) The Americas before and after 1492: An introduction to current geographical research. Annals, Association of American Geographers, Vol. 82, 345-368.

Butzer, K. W. (1996) Ecology in the long view: Settlement histories, agrosystemic strategies, and ecological performance. Journal of Field Archaeology, Vol. 23, 141-150.

Carter, W. B. (2009) Indian Alliances and the Spanish in the Southwest, 750-1750. Norman, OK: University of Oklahoma Press. 
Clark, J. S. and Royall, P. D. (1995) Transformation of a northern hardwood forest by aboriginal (Iroquois) fire: Charcoal evidence from Crawford Lake, Ontario, Canada. The Holocene, Vol. 5, 1-9.

Costa, J.E. (1975) Effects of agriculture on erosion and sedimentation in the Piedmont Province, Maryland. Geological Society of America Bulletin, Vol. 86, 1281-1286.

Cunliffe, B. (2008) Europe Between the Oceans. Themes and Variation: 9000 BC-AD 1000. New Haven, CT and London, UK: Yale University Press.

Dean, W., Ahlbrandt, T., Anderson, R., and Bradbury, J. P. (1996) Regional aridity in North America during the middle Holocene. The Holocene, Vol. 6, 145-155.

Delcourt, P. A. and Delcourt, H. R. (1987) Long-Term Forest Dynamics of the Temperate Zone: A Case Study of Late-Quaternary Forests in Eastern North America. New York, NY: Springer-Verlag.

Delcourt, P. A. and Delcourt, H. R. (2004) Prehistoric Native Americans and Ecological Change. Cambridge, UK: Cambridge University Press.

de Moor, J. J. W., Kasse, C., van Balen, R., Vandenberghe, J., and Wallinga, J. (2008) Human and climate impact on catchment development during the Holocene: The Geul River, the Netherlands. Geomorphology, Vol. 98, 316-339.

Denevan, W. M. (1992a) The Native Population of the Americas in 1492, second edition. Madison, WI: University of Wisconsin Press.

Denevan, W. M. (1992b) The pristine myth: The landscape of the Americas in 1492. Annals, Association of American Geographers, Vol. 82, 369-385.

Denevan, W. M. (2003) Cultivated Landscapes of Native Amazonia and the Andes. New York, NY: Oxford University Press.

Denevan, W. M. (2006) Charles Mann and humanized landscapes: Review. Geographical Review, Vol. 96, 483-486.

Diamond, J. (1997) Guns, Germs, and Steel: The Fates of Human Societies. New York, NY: W. W. Norton \& Company.

Donkin, R. A. (1979) Agricultural Terracing in the Aboriginal New World. Tucson, AZ: University of Arizona Press, Viking Fund Publications in Anthropology 56.

Doolittle, W. E. (1992) Agriculture in North America on the eve of contact: A reassessment. Annals, Association of American Geographers, Vol. 82, 386-401.

Doolittle, W. E. (2000) Cultivated Landscapes of Native North America. New York, NY: Oxford University Press.

Faulkner, D. J. (1998) Spatially variable historical alluviation and channel incision in west-central Wisconsin. Annals, Association of American Geographers, Vol. 88, 666-685.

Florsheim, J. L. and Mount, J. F. (2003) Changes in lowland floodplain sedimentation processes: Pre-disturbance to post-rehabilitation, Cosumnes River, CA. Geomorphology, Vol. 56(3-4), 305-323.

Foster, D. R., Motzkin, G., and Slater, B. (1998) Land use history as long-term broadscale disturbance: Regional forest dynamics in central New England. Ecosystems, Vol. 1, 96-119.

Goudie, A. (2005) The Human Impact on the Natural Environment: Past, Present, Future, sixth edition. Oxford, UK: Blackwell Science Publishing. 
Happ, S. C. (1944) Effect of sedimentation on floods in the Kickapoo Valley, Wisconsin. Journal of Geology, Vol. 52, 53-68.

Happ, S. (1945) Sedimentation in South Carolina Piedmont valleys. American Journal of Science, Vol. 243, 113-126.

Harkin, M. E. and Lewis, D. R. (2007) Introduction. In M. E. Harkin and D. R. Lewis, eds., Native America and the Environment: Perspective on the Ecological Indian. Lincoln, NE: University of Nebraska Press, xix-xxxiv.

Hilfinger, M. F., IV, Mullins, H. T., Burnett, A. W., and Kirby, M. E. (2001) A 2500-year sediment record from Fayetteville Green Lake, New York: Evidence for anthropogenic impacts and historic isotope shift. Journal of Paleolimnology, Vol. 26, 293-305.

Hilgartner, W. B. and Brush, G. S. (2006) Prehistoric habitat stability and postsettlement habitat change in a Chesapeake Bay freshwater tidal wetland, USA. The Holocene, Vol. 16, 479-494.

Hobson, J. M. (2004) The Eastern Origins of Western Civilisation. Cambridge, UK: Cambridge University Press.

Hubeny, J. B., King, J. W., and Cantwell, M. (2009) Anthropogenic influences on estuarine sedimentation and ecology: Examples from the varved sediments of the Pettaquamscutt River Estuary, Rhode Island. Journal of Paleolimnology, Vol. 41, 297-314.

Hupy, C. M. and C. H. Yansa (2009) Late Holocene vegetation history of the forest tension zone in central lower Michigan, USA. Physical Geography, Vol. 30, 205-235.

Hyatt, J. A. and Gilbert, R. (2000) Lacustrine sedimentary record of human-induced gully erosion and land use change at Providence Canyon, southwest Georgia, USA. Journal of Paleolimnology, Vol. 23, 421-438.

Jacobson, R. B. and Coleman, D. J. (1986) Stratigraphy and recent evolution of Maryland Piedmont flood plains. American Journal of Science, Vol. 286, 617-637.

James, L. A. (1989) Sustained storage and transport of hydraulic mining sediment in the Bear River, California. Annals, Association of American Geographers, Vol. 79, 570-592.

James, L. A. (1991) Incision and morphological evolution of a channel recovering from hydraulic mining sedimentation. Geological Society of America Bulletin, Vol. 103, 723-726.

James, L. A. (2006) Bed waves at the basin scale: Implications for river management and restoration. Earth Surface Processes and Landforms, Vol. 31, 1692-1706.

James, L. A. (2010) Secular sediment waves, channel-bed waves, and legacy sediment. Geography Compass, doi: 10.1111/j.1749-8198.2010.00324.x

James, L. A., Singer, M. B., Ghoshal, S., and Megison, M. (2009) Historical channel changes in the lower Yuba and Feather rivers, California: Long-term effects of contrasting river-management strategies. In L. A. James, S. L. Rathburn, and G. R.Whittecar, eds., Management and Restoration of Fluvial Systems with Broad Historical Changes and Human Impacts. Boulder, CO: Geological Society of America Special Paper 451, 57-81. 
Knox, J. C. (1972) Valley alluviation in southwestern Wisconsin. Annals, Association of American Geographers, Vol. 62, 401-410.

Knox, J. C. (1977) Human impacts on Wisconsin stream channels. Annals, Association of American Geographers, Vol. 77, 323-342.

Knox, J. C. (1987) Historical valley floor sedimentation in the Upper Mississippi Valley. Annals, Association of American Geographers, Vol. 77, 224-244.

Knox, J. C. (2001) Agricultural influence on landscape sensitivity in the Upper Mississippi River Valley. Catena, Vol. 42, 193-224.

Knox, J. C. (2002) Agriculture, erosion, and sediment yields. In A. R. Orme, ed., The Physical Geography of North America. Oxford, UK: Oxford University Press, 482-500.

Knox, J. C. (2006) Floodplain sedimentation in the upper Mississippi Valley: Natural versus human accelerated. Geomorphology, Vol. 79, 286-310.

Krech, S., III (1999) The Ecological Indian: Myth and History. New York, NY: W.W. Norton.

Krober, A. L. (1922) Elements of culture in native California. University of California Publications in American Archaeology and Ethnology, Vol. 13, 260-328 (reprinted in R. F. Heiser and M. A. Whipple, eds. (1971) The California Indians-A Source Book. Berkeley, CA: University of California Press, 39-43).

Lang, A., Bork, H.-R., Mäckel, R., Preston, N., Wunderlich, J., and Dikau, R. (2003) Changes in sediment flux and storage within a fluvial system: Some examples from the Rhine catchment. Hydrologic Processes, Vol. 17, 3321-3334.

Lecce, S. A. (1997) Spatial patterns of historical overbank sedimentation and floodplain evolution, Blue River Wisconsin. Geomorphology, Vol. 18, 265-277.

Lecce, S. A. and Pavlowsky, R. T. (2001) Use of mining-contaminated sediment tracers to investigate the timing and rates of historical flood plain sedimentation. Geomorphology, Vol. 38, 85-108.

Lecce, S. A. and Pavlowsky, R. T. (2004) Spatial and temporal variations in the grainsize characteristics of historical flood plain deposits, Blue River, Wisconsin, USA. Geomorphology, Vol. 61, 361-371.

Lentz, D. L., ed. (2000) Imperfect Balance: Landscape Transformations in the PreColumbian Americas. New York, NY: Columbia University Press, The Historical Ecology Series.

Magilligan, F. J. (1985) Historical floodplain sedimentation in the Galena River basin, Wisconsin and Illinois. Annals, Association of American Geographers, Vol. 75, 583-594.

Magilligan, F. J. (1992) Sedimentology of a fine-grained aggrading floodplain. Geomorphology, Vol. 4, 393-408.

Magilligan, F. J. and Stamp, M. L. (1997) Historical land-cover changes and hydrogeomorphic adjustment in a small Georgia watershed. Annals, Association of American Geographers, Vol. 87, 614-635.

Mann, C. C. (2005) 1491: New Revelations of the Americas before Columbus. New York, NY: A. A. Knopf.

McAndrews, J. H. (1988) Human disturbance of North American forests and grasslands: The fossil pollen record. In B. Huntley and T. Webb, III, eds., Vegetation 
History. Utrecht, The Netherlands: Kluwer, Handbook of Vegetation Science series, 673-697.

Meltzer, D. J. (1999) Human responses to middle Holocene (Altithermal) climates on the North American Great Plains. Quaternary Research, Vol. 52, 404-416.

Merritts, D. J., Walter, R., Rahnis, M., and 25 others (2011) Anthropocene streams and base-level controls from historic dams in the unglaciated mid-Atlantic region, USA. Philosophical Transactions of the Royal Society, A, Vol. 369 (1938), 976-1009.

Miller, S. O., Ritter, D. F., Kochel, R. C., and Miller, J. R. (1993) Fluvial responses to land use changes and climatic variations within the Drury Creek watershed, southern Illinois. Geomorphology, Vol. 6, 309-329.

Montgomery, D. R. (2007) Soil erosion and agricultural sustainability. Proceedings, National Academy of Sciences, Vol. 104(33), 13268-13272.

Muller, J. (1978) The Kincaid system: Mississippian settlement in the environs of a large site. In B. D. Smith, ed., Mississippian Settlement Patterns. New York, NY: Academic Press, 233-268.

Mullins, H. T., Patterson, W. P., Teece, M. A., and Burnett, A. W. (2011) Holocene climate and environmental change in central New York (USA). Journal of Paleolimnology, Vol. 45, 243-256.

Munoz, S. E. and Gajewski, K. (2010) Distinguishing prehistoric human influence on late-Holocene forests in southern Ontario, Canada. The Holocene, Vol. 20, 967-981.

Pasternack, G. B., Brush, G. S., and Hilgartner, W. B. (2001) Impact of historic land use change on sediment delivery to a Chesapeake Bay subestuarine delta. Earth Surface Processes and Landforms, Vol. 26, 409-427.

Phillips, J. D. (1992) The source of alluvium in large rivers of the lower Coastal Plain of North Carolina. Catena, Vol. 19, 59-75.

Phillips, J. D. (1993) Pre- and post-colonial sediment sources and storage in the lower Neuse River basin, North Carolina. Physical Geography, Vol. 14, 272-284.

Phillips, J.D. (1997) Human agency, Holocene sea level, and floodplain accretion in Coastal Plain rivers. Journal of Coastal Research, Vol. 13, 854-866.

Powers, S. (1877) Tribes of California. Contributions to North American Ethnology 3. Washington, DC: U.S. Government Printing Office, U.S. Geographical and Geological Survey of the Rocky Mountain Region.

Redman, C. L. (1999) Human Impact on Ancient Environments. Tucson, AZ: University of Arizona Press.

Rosenthal, J. S., White, G. G., and Sutton, M. Q. (2007) The Central Valley: A view from the catbird's seat. In T. L. Jones and A. A. Klar, eds., California Prehistory: Colonization, Culture, and Complexity. New York, NY: Rowman and Littlefield, 147-163.

Ruhlman, M. B. and Nutter, W. L. (1999) Channel morphology evolution and overbank flow in the Georgia Piedmont. Journal, American Water Resources Association, Vol. 35, 277-290.

Sassaman, K. E. (1996) Early Archaic settlement in the South Carolina Coastal Plan. In D. G. Anderson and K. E. Sassaman, eds., The Paleoindian and Early Archaic Southeast. Tuscaloosa, AL: University of Alabama Press, 58-83. 
Schuldenrein, J. (1996) Geoarchaeology and the mid-Holocene landscape history of the greater Southeast. In K. E. Sassaman and D. G. Anderson, eds., Archaeology of the Mid-Holocene Southeast. Gainesville, FL: University of Florida Press, 3-27.

Springer, G. S., White, D. M., Rowe, H. D., Hardt, B., Mihimdukulasooriya, L. N., Cheng, H., and Edwards, R. L. (2010) Multiproxy evidence from caves of Native Americans altering the overlying landscape during the late Holocene of eastcentral North America. The Holocene, Vol. 20, 275-283.

Taylor, R. E., Haynes, C. V., Jr., and Stuiver, M. (1996) Clovis and Folsom age estimates: Stratigraphic context and radiocarbon calibration. Antiquity, Vol. 70, 1-11.

Thornton, R. (1987) American Indian Holocaust and Survival: A Population History Since 1492. Norman: University of Oklahoma Press, Civilization of the American Indian Series.

Trimble, S. W. (1974) Man-Induced Soil Erosion on the Southern Piedmont, 17001970. Ankeny, IA: Soil Conservation Society of America.

Trimble, S. W. (1977) The fallacy of stream equilibrium in contemporary denudation studies. American Journal of Science, Vol. 277, 876-887.

Vale, T. R. (1998) The myth of the humanized landscape: An example from Yosemite National Park. Natural Areas Journal, Vol. 18, 231-236.

Vale, T. R. (2002) The pre-European landscape of the United States: Pristine or humanized? In T. R. Vale, ed., Fire, Native Peoples, and the Natural Landscape. Covelo, CA: Island Press, 1-39.

Van Andel, T. H., Zangger, E., and Demitrack, A. (1990) Land use and soil erosion in prehistoric and historical Greece. Journal of Field Archaeology, Vol. 17, 379-396.

Walter, R. C. and D. J. Merritts (2009) Natural streams and the legacy of waterpowered mills. Science, Vol. 319, 299-304.

Waters, M. R. and Nordt, L. (1995) Late Quaternary floodplain history of the Brazos River, Texas. Quaternary Research, Vol. 43, 311-319.

Waters, M. R. and Stafford, T. W., Jr. (2007) Redefining the Age of Clovis: Implications for the peopling of the Americas. Science, Vol. 315, 1122-1126.

Whitmore, T. M. and Turner, B. L., II (2002) Cultivated Landscapes of Middle America on the Eve of Conquest. New York, NY: Oxford University Press.

Wilkinson, B. H. (2005) Humans as geologic agents: A deep-time perspective. Geological Society of America Bulletin, Vol. 33, 161-164.

Wolman, M. G. and Miller, J. P. (1960) Magnitude and frequency of forces in geomorphic processes. Journal of Geology, Vol. 68, 54-74.

Wolman, M. G. and Gerson, R. (1978) Relative scales of time and effectiveness of climate in watershed geomorphology. Earth Surface Processes and Landforms, Vol. 3, 189-208. 